16

17 18

\title{
Conifer Density within Lake Catchments Predicts Fish Mercury Concentrations in Remote Subalpine Lakes
}

\author{
Collin A. EAgles-SMith ${ }^{1 *}$, GARTH Herring ${ }^{1}$, BRANDEN JOHNSON ${ }^{1}$, AND RicK \\ GRAW $^{2}$
}

\footnotetext{
${ }^{1}$ U.S. Geological Survey, Forest and Rangeland Ecosystem Science Center, Corvallis Research Group, 3200 SW Jefferson Way, Corvallis, OR 97331, USA

${ }^{2}$ U. S. Department of Agriculture Forest Service

*Corresponding author

Email: ceagles-smith@usgs.gov

Tel: $1+541-750-0949$

Fax: 1+ 541-750-1069

Word Count: 5,368
} 


\section{Abstract}

Remote high-elevation lakes represent unique environments for evaluating the bioaccumulation of atmospherically deposited mercury through freshwater food webs, as well as for evaluating the relative importance of mercury loading versus landscape influences on mercury bioaccumulation. The increase in mercury deposition to these systems over the past century, coupled with their limited exposure to direct anthropogenic disturbance make them useful indicators for estimating how changes in mercury emissions may propagate to changes in $\mathrm{Hg}$ bioaccumulation and ecological risk. We evaluated mercury concentrations in resident fish from 28 high-elevation, sub-alpine lakes in the Pacific Northwest region of the United States. Fish total mercury (THg) concentrations ranged from 4 to $438 \mathrm{ng} / \mathrm{g}$ wet weight, with a geometric mean concentration ( \pm standard error) of $43 \pm 2 \mathrm{ng} / \mathrm{g}$ ww. Fish $\mathrm{THg}$ concentrations were negatively correlated with relative condition factor, indicating that faster growing fish that are in better condition have lower THg concentrations. Across the 28 study lakes, mean $\mathrm{THg}$ concentrations of resident salmonid fishes varied as much as 18 -fold among lakes. We used a hierarchal statistical approach to evaluate the relative importance of physiological, limnological, and catchment drivers of fish $\mathrm{Hg}$ concentrations. Our top statistical model explained $87 \%$ of the variability in fish $\mathrm{THg}$ concentrations among lakes with four key landscape and limnological variables: catchment conifer density (basal area of conifers within a lake's catchment), lake surface area, aqueous dissolved sulfate, and dissolved organic carbon. Conifer density within a lake's catchment was the most important variable explaining fish $\mathrm{THg}$ concentrations across lakes, with $\mathrm{THg}$ concentrations differing by more than 400 percent across the forest density spectrum. These results illustrate the importance of landscape characteristics in controlling mercury bioaccumulation in fish.

Capsule - Mercury concentrations subalpine lake fish were highly variable across lakes, with variation largely driven by conifer density within catchments, lake size, and water chemistry.

Keywords - Mercury, Fish, Landscape, Bioaccumulation, Forest, Conifer, Condition Factor 


\section{Introduction}

Mercury $(\mathrm{Hg})$ is a globally distributed pollutant that poses considerable risks to human and wildlife health (Scheuhammer and Sandheinrich, 2008). Under appropriate biogeochemical conditions in aquatic ecosystems, inorganic $\mathrm{Hg}$ is microbially converted to the highly toxic and bioavailable organic form, methylmercury $(\mathrm{MeHg})$, which biomagnifies through food webs where it can reach toxicologically relevant concentrations in top predators. As a result, the ecological risk of $\mathrm{Hg}$ is driven by a combination of both inorganic loading, as well as ecological parameters that facilitate $\mathrm{MeHg}$ production and bioaccumulation. Inland lakes are particularly vulnerable to $\mathrm{Hg}$ contamination because they are recipients of transported $\mathrm{Hg}$, and their organic rich, anoxic sediments can promote $\mathrm{MeHg}$ production.

Lakes receive $\mathrm{Hg}$ from various sources, including atmospheric deposition, watershed runoff, and glacial meltwater (Rudd, 1995; St. Louis et al., 1994). Over the past 150-200 years since the advent of the industrial revolution, approximately 80 percent of global emissions have come from anthropogenic sources, largely fossil fuel combustion (Mason et al., 1994), but also gold mining, and manufacturing (Pirrone et al., 2010). Mercury also is re-emitted to the atmosphere from forest fires and agricultural burning (Friedli et al., 2003). As a result, atmospheric deposition of $\mathrm{Hg}$ in remote environments has increased by approximately 3 -fold (Lindberg et al., 2007). Importantly, there is substantial variability in the spatial patterns of anthropogenic $\mathrm{Hg}$ releases and deposition at local, regional, and global scales, associated with coal-fired power plants, industrial activity, and mining (Engstrom et al., 2007), as well as in the propensity of inorganic $\mathrm{Hg}$ to be methylated across the landscape. Therefore, it can be difficult to determine how much of the variability in $\mathrm{Hg}$ concentrations among systems can be attributed to $\mathrm{Hg}$ loading relative to in situ $\mathrm{MeHg}$ production.

Because of their isolation, remote high elevation lakes represent unique environments for evaluating the bioaccumulation of atmospherically deposited $\mathrm{Hg}$ through freshwater food webs, as well as for evaluating the relative importance of $\mathrm{Hg}$ loading versus landscape influences on $\mathrm{Hg}$ bioaccumulation. The increase in $\mathrm{Hg}$ deposition to these systems over the past century (Phillips et al., 2011), coupled with their limited exposure to direct anthropogenic disturbance make them useful indicators for estimating how changes in $\mathrm{Hg}$ emissions may propagate changes in $\mathrm{Hg}$ bioaccumulation and ecological risk. However, catchment structure of sub-alpine lakes can vary substantially in terms of forest density, which has been shown to influence fish $\mathrm{Hg}$ concentrations in lower elevation lakes with greater catchment areas (Drenner et al., 2013), thus it may be important to account for tree density in subalpine lake catchments because conifers can adsorb $\mathrm{Hg}$ from the atmosphere, resulting in increased deposition rates

In this study, we evaluated $\mathrm{Hg}$ bioaccumulation in fishes of high elevation, sub-alpine lakes in the Wallowa-Whitman National Forest in northeastern Oregon and western Idaho (Figure 1). Our goals were to (1) assess the magnitude of $\mathrm{Hg}$ contamination in a collection of small-catchment lakes, (2) quantify the spatial variability in fish $\mathrm{Hg}$ 
94

concentration across these lakes, and (3) determine the physiological, limnological, and landscape factors that are most strongly related to fish $\mathrm{THg}$ concentrations.

\section{Methods}

\section{Site Description and Field Collection}

The Wallowa-Whitman National Forest in northeastern Oregon and western Idaho occupies more than $9,000 \mathrm{~km}^{2}$ of land, including nearly $2,500 \mathrm{~km}^{2}$ of designated wilderness. The forest is comprised of varied landscapes including low-elevation grasslands, coniferous forests, and alpine meadows. High-elevation habitats are found in the Elkhorn Mountains, the Wallowa Mountains and Eagle Cap Wilderness, and the Hells Canyon National Recreation Area. Throughout the region there are small $\left(<0.5 \mathrm{~km}^{2}\right)$, high-elevation $(>2,000 \mathrm{~m}$ ) lakes within isolated catchments that have naturally reproducing populations of brook trout (Salvelinus fontinalis) and rainbow trout (Oncorhynchus mykiss) as a result of historical fish stocking for recreational purposes (Figure S1). These lakes are solely catchment or groundwater fed, and $\mathrm{Hg}$ sources are largely limited to atmospheric deposition because they do not have inflowing streams, and are not known to have mercury-enriched geologic deposits. The catchments associated with these lakes generally are small $\left(<5 \mathrm{~km}^{2}\right)$, and comprised of a combination of open, rocky terrain, and temperate, subalpine coniferous forest.

Between July 11 and September 1, 2011 we sampled brook trout, rainbow trout, cutthroat trout (Oncorhynchus clarkii), and lake trout (Salvelinus namaycush) from 28 different lakes within 5 geographic regions (North Elkhorn, South Elkhorn, North Eagle Cap, South Eagle Cap, and Seven Devils) of the Wallowa-Whitman National Forest (Table S1, Figure S1). Visits to lakes were randomized over that time-frame to prevent sampling date from confounding regional $\mathrm{Hg}$ assessments. Fish were sampled using both hook and line and $30 \mathrm{~m} \times 2 \mathrm{~m}$ variable-mesh gillnets and were only retained if they exceeded lengths of stocked fish so we could control for any stocking effect. Upon collection fish were immediately wrapped in clean, solvent-rinsed aluminum foil and sealed in individually labeled polyethylene bags. Each bagged fish was kept cool on ice or snow until delivery to the laboratory (within $48 \mathrm{hrs}$ ), where they were stored at $-20^{\circ} \mathrm{C}$ until processing. At 21 of the lakes, we also collected water samples in $125 \mathrm{~mL}$ acidcleaned amber glass bottles for water chemistry analysis.

\section{Fish Sample Processing and Tissue Preparation}

In the laboratory, we thawed each fish sample to room temperature, and then measured standard length to the nearest millimeter on a fish board and mass to the nearest $0.1 \mathrm{~g}$ on a digital balance. We calculated the body condition of each fish using the Relative Condition Factor $\left(\boldsymbol{K}_{\mathrm{n}}\right)$, which accounts for potential changes in shape as fish grow (Anderson and Neumann, 1996). The relative condition factor was calculated as:

$$
\boldsymbol{K}_{\mathrm{n}}=\boldsymbol{W} / \boldsymbol{W}^{\prime},
$$

Where: $\quad \boldsymbol{W}=$ fish whole body mass, in $\mathrm{g}$ and, 
$\boldsymbol{W}^{\prime}=$ the predicted length-specific mean mass from a predictive length-mass regression model calculated for each species.

To determine $\mathrm{W}^{\prime}$ for each species, we used $\log _{10}$-transformed standard length $(\mathrm{mm})$ and $\log _{10}$-transformed wet mass $(\mathrm{g}$ ) data for all fish of each species, from all lakes in which they were captured (brook trout linear regression: $n=230, r^{2}=0.96$, intercept $=-$ 11.646, slope $=3.099$; rainbow trout linear regression: $n=85, r^{2}=0.91$, intercept $=$ 10.696 , slope $=2.913$; cutthroat trout linear regression: $n=11, r^{2}=0.97$, intercept $=-$ 10.520 , slope $=2.854$ ). From each fish, we dissected 5-10 g of skinless axial muscle, rinsed the muscle tissue in deionized water, blotted it dry with a clean, lint-free wipe, and weighed it on an analytical balance to the nearest $0.0001 \mathrm{~g}$. We then dried each muscle sample in a convection oven at $50^{\circ} \mathrm{C}$ for $48 \mathrm{~h}$, or until a constant mass was achieved. We subsequently removed the samples from the drying oven and allowed them to cool to room temperature in a desiccator. Once cool, we measured the dry mass of each muscle tissue sample to the nearest $0.0001 \mathrm{~g}$, and ground them to a fine powder in a stainless steel tissue mill. The homogenized samples were then stored in a dark desiccator until chemical analyses.

\section{Mercury Determination}

We determined total mercury ( $\mathrm{THg}$ ) concentrations on skinless axial muscle of each fish sample because most (90-95\%) of mercury in fish muscle tissue is in the methylmercury (MeHg) form (Bloom, 1992). Total Hg concentrations were determined following EPA method 7473 (EPA, 2000) on a Milestone tri-cell DMA-80 Direct Mercury Analyzer (Milestone Inc, Monroe, Connecticut, USA) at the USGS Forest and Rangeland Science Center's Contaminant Ecology Laboratory in Corvallis, Oregon. Briefly, we used an integrated sequence of drying $\left(250^{\circ} \mathrm{C}\right.$ for $\left.30 \mathrm{~s}\right)$, thermal decomposition $\left(650^{\circ} \mathrm{C}\right.$ for $\left.90 \mathrm{~s}\right)$, catalytic conversion, and then amalgamation, followed by cold vapor atomic absorption spectroscopy. Unless stated otherwise, we analyzed and report all muscle tissue samples on a dry weight basis in order to control for variable moisture content among individuals. However, to facilitate comparison to other studies and to allow conversion to wet weight concentrations we determined moisture content in each sample. Moisture content in the fish muscle tissue ranged from 74.7 to 85.8 percent with a mean ( \pm standard error) of $79.8 \pm 0.1 \%$.

Quality-assurance measures included analysis of two certified reference materials (either dogfish muscle tissue [DORM-3; National Research Council of Canada, Ottawa, Canada], or dogfish liver [DOLT-3; National Research Council of Canada, Ottawa, Canada], two system and method blanks, and two duplicates per batch of 30 samples. Recoveries ( \pm standard error [SE]) averaged $99.4 \pm 1.8$ percent $(n=60)$ and $97.9 \pm 0.8$ percent $(n=90)$ for certified reference materials and calibration checks, respectively. Absolute relative percent difference for all duplicates averaged $3.4 \pm 0.5$ percent.

\section{Water Chemistry}

All water samples were shipped immediately to the USDA Forest Service Air Program Biogeochemistry Laboratory in Fort Collins, Colorado. Prior to analysis water samples were filtered through $0.7-\mu \mathrm{m}$ glass fiber filters under gentle vacuum. 
176

177

178

179

180

181

182

183

184

185

186

187

188

189

190

191

192

193

194

195

196

197

198

199

200

201

202

203

204

205

206

207

208

209

210

211

212

213

214

215

216

217

218

Conductivity and $\mathrm{pH}$ were determined with a Metrohm/Brinkman Model 712 conductivity meter and Metrohm/Brinkman Model $809 \mathrm{pH}$ meter, respectively. Acid neutralizing capacity (ANC) was determined using the Gran analysis technique (Gran, 1952). Anions $\left(\mathrm{F}^{-}, \mathrm{Cl}^{-}, \mathrm{NO}_{2}{ }^{-}, \mathrm{NO}_{3}{ }^{-}, \mathrm{SO}_{4}{ }^{2-}\right)$ and cations $\left(\mathrm{Na}^{+}, \mathrm{NH}_{4}{ }^{+}, \mathrm{K}^{+}, \mathrm{Mg}_{2}{ }^{+}, \mathrm{Ca}_{2}{ }^{+}\right)$were measured with a Metrohm Model 838 Compact Ion Chromatograph). Dissolved organic carbon (DOC) was quantified on a Shimadzu TOC-5000 analyzer.

\section{Geospatial and Remote Sensing Analysis}

We characterized the spatial and physical attributes of the study lakes and their catchments using ArcMap 10 (ESRI, Redlands, California, USA). We first combined 10$m$ resolution digital elevation models (DEM) and the National Hydologic Dataset within the Spatial Analyst tool framework and then delineated areas of internal drainage and water accumulation in the DEM in order to assign a flow path to each grid cell. These estimates of flow direction and accumulation were integrated across the DEM and overlaid on the National Hydrological Dataset layer to determine "pour points" for delineating catchments. We used this approach to delineate the catchments for each lake, and then we reviewed those generated polygon boundaries against 1:24,000 USGS topographic maps and aerial photography to ensure accuracy. Within each catchment, we extracted lake elevation from the DEM and determined lake morphometry (lake surface area, maximum length, and perimeter) from the National Hydrological Dataset. Although it is well established that percent wetland area within a catchment can be an important driver of lake $\mathrm{MeHg}$ concentrations (Shanley et al., 2005), many of these catchments had limited wetland coverage, and geospatial wetland inventories lacked the resolution necessary to conduct statistically robust analyses. Therefore, we did not address wetland influences in this study.

In order to assess landscape-level influences on fish $\mathrm{THg}$ concentrations, we estimated forest structure within the catchment of each lake. We used 30-m resolution grid-based forest composition and structure data derived from the Gradient Nearest Neighbor imputation methods (Ohmann and Gregory, 2002). Data were acquired from the Landscape Ecology, Modeling, Mapping, and Analysis team

(http://www.fsl.orst.edu/lemma/). The Gradient Nearest Neighbor models provide estimates for forest parameters, such as basal area, tree density, stand age, and cover class. Using the output from these geospatial models, we characterized the total basal area $\left(\mathrm{m}^{2} / \mathrm{ha}\right)$ of conifers $(\geq 2.5 \mathrm{~cm}$ diameter at breast height $[\mathrm{dbh}])$ within the catchment of each lake (Figure 2). Basal area is a common metric of forest structure that is related to both the density and size distribution of trees in an area. Basal area is generally correlated with canopy cover, but can be a better estimate of tree biomass because it is less sensitive to variation due to crown overlap.

\section{Statistical Analyses}

Our statistical approach was designed to both quantify the spatial variability of fish $\mathrm{THg}$ concentrations among lakes and regions in the WWNF, and to evaluate the relationships between fish $\mathrm{THg}$ concentrations and key limnological, and landscape variables across the study lakes. To do this, we employed a 2-tiered statistical approach using mixed-effects general linear models. This process allowed us to statistically control 
for individual-level factors that influence fish $\mathrm{THg}$ concentrations (such as species, fish size, and body condition) in order to generate comparable model estimates of lakespecific least-square mean fish $\mathrm{THg}$ concentrations. These lake-specific means could then be used to test relative importance of the landscape and limnological variables on those THg concentrations.

Our primary goal in our first tier analysis was to make comparisons of fish $\mathrm{THg}$ concentrations among lakes. To do this we needed to statistically control for the effects of species, fish length, and fish body condition. We used a nested mixed-effects general linear model with region and lake (nested within region) included as fixed factors, and relative condition factor $\left(\boldsymbol{K}_{\mathrm{n}}\right)$ and standard length covariates. We also included a species $\mathrm{x}$ standard length interaction term in the model in order to test whether the relationship between THg concentrations and fish size differed among species. Species was included as a random effect because we were limited in the number of lakes from which rainbow trout and brook were sampled together.

In order to examine the relationships between landscape factors and fish $\mathrm{THg}$ concentrations, we used the lake-specific least-square mean fish $\mathrm{THg}$ concentrations from the primary global model described above to statistically account for the simultaneous varying effects of fish species, fish size, and body condition, providing standardized estimates of fish $\mathrm{Hg}$ concentrations among lakes. We used these estimates as the response variables in general linear models, following an information-theoretic framework (Burnham and Anderson, 2002) using R software (R Development Core Team, 2011), to determine the model structure and variables that most influenced $\mathrm{Hg}$ bioaccumulation in these subalpine lakes. We built and ranked separate competing $\boldsymbol{a}$ priori candidate models to understand how fish $\mathrm{THg}$ concentrations varied in response to select physical and chemical variables of lakes and their catchments. Physical variables included lake surface area $\left(\mathrm{km}^{2}\right)$, lake elevation $(\mathrm{m})$, lake catchment area $\left(\mathrm{km}^{2}\right)$, and the lake area:catchment area ratio. We also included the remotely sensed estimates of the basal area $\left(\mathrm{m}^{2} / \mathrm{ha}\right)$ of conifers $\geq 2.5 \mathrm{~cm}$ dbh within each lake's catchment. This commonly used silvicultural index integrates conifer stand density, age, and size to provide an approximation of conifer biomass within lake catchments. Lake chemical variables included $\mathrm{pH}$, acid neutralizing capacity (ANC; $\mu \mathrm{eq} / \mathrm{L})$, dissolved sulfate $\left(\mathrm{SO}_{4} ; \mathrm{mg} / \mathrm{L}\right)$, and dissolved organic carbon (DOC; mg/L). We also included an intercept only model and a global model. Mercury concentrations were natural log transformed to improve residual normality. Because we lacked water chemistry data from 30 percent of our lakes, we first considered models from the reduced sample size where we had both chemical and physical data $(\mathrm{N}=18)$. We then conducted a similar analysis using the larger lake sample size for which we had only the physical parameter measurements $(\mathrm{N}=26)$.

We used Akaike's information criterion adjusted for small samples sizes (AICc) and considered the model with the lowest AICc value to be the most parsimonious (Burnham and Anderson, 2002). We included all possible variable combinations to ensure a balanced design to facilitate comparison of variable weights. However, to ensure that the number of parameters in each model did not exceed what was appropriate for our samples size, we limited the total number of variables simultaneously included in any given model to four. We determined the relative ranking of each model by subtracting each candidate model's AICc value from the best model $(\triangle \mathrm{AICc})$. Candidate models were considered to 
264

265

266

267

268

269

270

271

272

273

274

275

276

277

278

279

280

281

282

283

284

285

286

287

288

289

290

291

292

293

294

295

296

297

298

299

300

301

302

be competitive when $\triangle \mathrm{AICc} \leq 2.0$. We calculated Akaike weights $\left(\mathrm{w}_{i}\right)$ to assess the weight of evidence that the selected model was the best candidate model (Burnham and Anderson, 2002). We also calculated variable weights by summing Akaike weights across all models that included the variable to assess the relative importance of each variable. We calculated model-averaged beta coefficient estimates from all candidate models (Burnham and Anderson, 2002).

Unless stated otherwise, all data are presented as back-transformed least-square means from model output, and standard error values are estimated using the Delta method (Williams et al., 2002).

\section{Results}

Descriptive Summary Results

We collected and analyzed a total of 327 fish, comprised of 4 species from 28 individual lakes, across 5 regions in the Wallowa-Whitman National Forest (Table 1). The geometric mean ( \pm standard error) fish $\mathrm{THg}$ concentrations $(\mu \mathrm{g} / \mathrm{g} \mathrm{dw})$ across all regions, lakes, and fish lengths, were $0.23 \pm 0.01$ in brook trout $(\mathrm{N}=230), 0.17 \pm 0.01$ in rainbow trout $(\mathrm{N}=85), 0.24 \pm 0.03$ in cutthroat trout $(\mathrm{N}=11)$, and 2.13 in lake trout $(\mathrm{N}=1)$.

\section{Spatial Patterns and Size Effects}

Fish $\mathrm{THg}$ concentrations differed among regions $\left(\mathrm{F}_{4,262.7}=60.26, \mathrm{P}<0.001\right)$, as well as among lakes nested within region $\left(\mathrm{F}_{22,252.3}=15.62, \mathrm{P}<0.001\right)$. Fish $\mathrm{THg}$ concentrations were highest in the North Elkhorn $(0.367 \pm 0.032)$ and Seven Devils $(0.320 \pm 0.035)$ regions and lowest in the North Eagle Cap region $(0.129 \pm 0.011$; Figure 3).

Lake-specific THg concentrations ranged from $0.040 \pm 0.007$ in Aneroid Lake (North Eagle Cap) to $0.718 \pm 0.111$ in Black Lake (North Elkhorn). Variation in fish THg concentrations generally was high in lakes both within, and among regions. Within regions, THg concentrations varied by approximately 5.6-fold in North Eagle Cap lakes, 5-fold in North Elkhorn lakes, 2.6-fold in South Elkhorn lakes, 2.4-fold in South Eagle Cap lakes, and 1.7-fold in Seven Devils lakes (Figure 4). In fact, even some lakes within less than $1 \mathrm{~km}$ from each other differed by up to a factor of 2. After statistically controlling for the simultaneous effects of lake, region, and standard length, fish $\mathrm{THg}$ concentrations were negatively correlated with the relative condition factor of individual fish $\left(\mathrm{F}_{1,282.8}=25.96, \mathrm{P}<0.001\right.$; Figure 5). In fact, modeled THg concentrations decreased 3 -fold across the range of fish condition factors.

\section{Landscape and Lake Effects}

The most parsimonious model explaining least-squares mean fish $\mathrm{THg}$ concentrations across lakes contained four variables: (1) basal area of conifers within a lake's catchment, (2) lake area, (3) dissolved $\mathrm{SO}_{4}$ concentration, and (4) DOC concentration. No other models were well supported (all $\Delta$ AICc $>2$ ), and the top model had an Akaike weight of 0.56 and was 1.6 times more likely than the next best model, which was identical to the 
top model with the exception that it did not include DOC (Table 2). Additionally, $87 \%$ of the variability in our data could be explained using the top model, whereas the next best model explained only $71 \%$. Using variable weights to assess the relative importance of each variable (Burnham and Anderson, 2002), models containing basal area of conifers had a combined AICc weight of 0.99 , followed by $\mathrm{SO}_{4}(0.96)$, and lake area (0.93), with moderate model support for DOCA (0.57), and little evidence for effects of ANC (0.10), catchment area (0.06), $\mathrm{pH}(0.05)$, elevation (0.03), or the lake area:catchment ratio (0.03).

Although the variable weight for DOC was moderate, the model averaged beta coefficient estimates for this variable had 95-percent confidence intervals that slightly overlapped zero $(\beta=-0.141 \pm 0.172)$ indicating that DOC had a smaller effect on fish $\mathrm{THg}$ concentrations than did basal area $(\beta=0.075 \pm 0.032), \mathrm{SO}_{4}(\beta=-0.329 \pm 0.150)$, or lake area $(\beta=-4.855 \pm 2.803)$. Using model-averaged estimates, the average basal area within a lake's catchment had an overriding influence on the fish $\mathrm{THg}$ concentrations, resulting in a $428 \%$ increase in fish $\mathrm{THg}$ concentrations from the catchment with the lowest conifer biomass to the catchment with the highest conifer biomass (Figure 6). Mercury concentrations also decreased by 24,72 , and $30 \%$ percent across the observed ranges of lake area, $\mathrm{SO}_{4}$, and DOC data, respectively (Figure 7).

Because we had a larger dataset of lakes for which only physical variables were available ( $\mathrm{N}=26$ vs. $\mathrm{N}=18)$, we also examined the influence of physical variables alone on the larger dataset. In this case, the most parsimonious model explaining fish $\mathrm{THg}$ concentrations again contained catchment basal area and lake surface area (Table 3). No other models were well supported (all $\Delta \mathrm{AICc}>2$ ), the top model had an Akaike weight of 0.51 and was more than 4 times more likely than the next best model, which also included the ratio of lake area to catchment area as a third variable (Table 3). Models containing catchment basal area had a combined AICc weight of 0.97 , followed by lake area (0.94), highlighting the overriding importance of those two variables in controlling fish $\mathrm{THg}$ concentrations in the absence of lake chemistry information. We found little evidence for effects of catchment area (0.19), elevation (0.18), or the lake area:catchment ratio (0.18). Importantly, by excluding the lake chemistry data, we reduced the predictive power of our model to explain only 47 percent of the variability in the data.

\section{DISCUSSION}

Across the 28 subalpine lakes that were sampled, we found wide variation in $\mathrm{THg}$ concentrations of fishes, both within and among lakes. We evaluated the within lake variation in fish $\mathrm{Hg}$ concentrations in the context of physiological drivers such as fish size and body condition, and the among-lake differences within the context of limnological and catchment drivers, such as water chemistry and catchment forest structure. Using this hierarchical approach, we found that drivers at both scales are important in determining fish $\mathrm{Hg}$ bioaccumulation and risk to wildlife and humans.

Within lakes we found that the influence of body condition on fish $\mathrm{Hg}$ concentrations was more consistent and stronger than was fish length. In fact, after controlling for size and site effects we found a nearly 3 -fold decrease in fish $\mathrm{THg}$ concentrations across a 
2.2-fold range of relative condition factors (0.64-1.42). Increases in $\mathrm{Hg}$ concentrations with increasing fish age, size, and trophic position are well-established processes (Wiener et al., 2007), but fish Hg concentrations also are influenced by a fish's growth rate (Trudel and Rasmussen, 2006). All else being equal, THg concentrations in faster growing fishes can be lower than those in slower growing fishes because the rate of biomass accretion exceeds the assimilation and retention of dietary $\mathrm{Hg}$ (Stafford et al., 2004). Fish condition (mass relative to length) is correlated with average growth rate (Ricker, 1979), but is generally more sensitive to short-term changes in environmental conditions (Dittman and Driscoll, 2009). Thus, changes in body condition may influence fish $\mathrm{Hg}$ concentrations within a more rapid timeframe than changes in structural growth rates. Understanding the dynamics of fish condition effects on $\mathrm{Hg}$ concentrations is important because fisheries managers can implement practices that may help lower $\mathrm{Hg}$ risk for certain fish populations simply by managing body condition. For example, a whole ecosystem experiment that stocked low $\mathrm{Hg}$, high energy density prey into a lake resulted in enhanced condition and up to a 50\% decline in top predator $\mathrm{Hg}$ concentrations after only approximately 51 days (Lepak et al., 2012). Similarly, a drastic reduction in top predator Northern Pike densities within a lake caused a $50 \%$ decline in the remaining pike THg concentrations after two years as a result of increased growth efficiency and condition (Sharma et al., 2008). Moreover, bioenergetics models coupled with $\mathrm{Hg}$ bioaccumulation models predict that shifts to prey with higher energy content can reduce THg concentrations in top predator fish (Johnson et al., 2015). Together, these results suggest that efforts to manage body condition of top predators may be an effective approach to reduce human and wildlife exposure to $\mathrm{Hg}$, particularly in waterbodies where $\mathrm{Hg}$ source control or management of the processes that influence $\mathrm{MeHg}$ production are not viable options.

Atmospheric deposition is the primary source of $\mathrm{Hg}$ to remote areas, such as the subalpine lakes (Phillips et al., 2011). This is particularly true of high-elevation lakes that are largely rain and snow-fed, and lie within relatively small catchments with limited upland transport from stream networks. Although there are no direct measurements of atmospheric $\mathrm{Hg}$ deposition within the study area, modeled estimates suggest that it may be elevated in comparison to much of the Pacific Northwest (http://nadp.sws.uiuc.edu/mdn/). This is likely due to both higher precipitation associated with orographic effects of the mountainous terrain, as well as a mixture of the global background $\mathrm{Hg}$ signal with more regional and localized $\mathrm{Hg}$ sources. Notably, until the recent implementation of $\mathrm{Hg}$ controls, one of the largest $\mathrm{Hg}$ emitting sites in the U.S. was approximately $60 \mathrm{~km}$ from the closest study lake (Schmeltz et al., 2011). The magnitude of current or historical $\mathrm{Hg}$ deposition from emission site to the subalpine catchments within the study area is unclear, but we found no evidence of a gradient in fish $\mathrm{THg}$ concentrations with respect to distance from the site. Instead, there was considerable spatial variability in fish $\mathrm{THg}$ concentrations among study lakes, where LS mean fish $\mathrm{THg}$ concentrations in lakes (statistically controlling for species, size, and body condition effects) varied by nearly 3 -fold within regions, and by 18 -fold across the entire study area. This variability in fish $\mathrm{Hg}$ concentrations among lakes despite their proximity to one another suggests that factors beyond just $\mathrm{Hg}$ deposition rates are likely important in driving fish bioaccumulation across the landscape. 
The physical and chemical characteristics of lakes and their catchments have often been linked with fish $\mathrm{Hg}$ concentrations because of their role in facilitating $\mathrm{MeHg}$ production, or in controlling $\mathrm{Hg}$ entry and transport through the food web (Snodgrass et al., 2000). Factors that are commonly correlated with those processes include wetland area, lake size, lake productivity, forest coverage, DOC, $\mathrm{pH}$, and sulfate (Driscoll et al., 2007; Greenfield et al., 2001; Hall et al., 2005; Shanley et al., 2012; St. Louis et al., 1994). However, with the exception of wetland area and $\mathrm{pH}$, there are conflicting data on the degree and direction of influence for many of the other parameters, largely due to the complexity of $\mathrm{Hg}$ cycling and methylation. Across lakes in this study, fish $\mathrm{THg}$ concentrations were strongly predicted by a combination of landscape and limnological factors. In fact, $87 \%$ of the variability in lake-specific LS mean fish THg concentrations was explained with a model containing (1) an index of conifer density (basal area) within a lake's catchment, (2) lake surface area, (3) lake water DOC concentrations, and (4) lake water sulfate concentrations. Of these factors, conifer density had the most influence on determining fish $\mathrm{THg}$ concentrations.

The role of DOC in the Hg cycle is complex (Lambertsson and Nilsson, 2006). Dissolved organic matter not only facilitates $\mathrm{Hg}$ transport through watersheds (Shanley et al., 2008), but also can enhance or reduce biological uptake (Dutton and Fisher, 2012; Wiener et al., 2006), as well as serve as a carbon source for microbial activity, increasing $\mathrm{MeHg}$ production rates (Lambertsson and Nilsson, 2006). The complexity of the role played by DOC in these processes is driven by both its quantity and composition (Shanley et al., 2012). We found negative correlations between DOC and fish THg concentrations across our study lakes, which is consistent with studies in midwestern seepage lakes where DOC in the water column commonly inhibits biological uptake of $\mathrm{MeHg}$ (Wren et al., 1991). This result by itself is not surprising given the fact that the lakes we studied lacked inflowing streams and were primarily fed through precipitation, catchment snowmelt, and groundwater. However, the strong positive influence of catchment vegetation (conifer basal area) on fish $\mathrm{THg}$ concentrations suggests the potential for a greater catchment influence, one where carbon supplied to the lake by the catchment may drive $\mathrm{Hg}$ bioaccumulation. Specifically, conifer density (basal area) within a lake's catchment was overwhelmingly the most important factor that we measured in driving the variation in fish $\mathrm{THg}$ concentrations among lakes. In fact, modelaveraged fish $\mathrm{THg}$ concentrations ranged from 0.11 to $0.58 \mu \mathrm{g} / \mathrm{g}$ dw between the lakes with the lowest and highest conifer density. This is a novel finding with the potential for wide-ranging implications in the management of $\mathrm{Hg}$ in forested catchments.

Forested lands can have a strong influence on $\mathrm{Hg}$ cycling within watersheds (Drenner et al., 2013; Obrist et al., 2011). At the landscape scale, Hg concentrations in waterbodies have been shown to positively correlate with percentage of forested area within large watersheds (Evers et al., 2011; Shanley et al., 2012), particularly coniferous forest area (Drenner et al., 2013). Our results are consistent with those past findings, but to our knowledge this is the first study that has quantified the influence of actual tree density on fish $\mathrm{THg}$ concentrations within closed catchment lakes. Determining the mechanism for this pattern is beyond the scope of the study, but is likely related to enhanced scavenging of $\mathrm{Hg}$ from the atmosphere coupled with forest runoff and organic matter influences to lake chemistry. Trees accumulate $\mathrm{Hg}$ from the atmosphere within their leaf tissue and 
conifers also provide substantial surface area for $\mathrm{Hg}$ deposition and adsorption to leaf surfaces (Graydon et al., 2008; Tebatchnick et al., 2012). This increase in surface area can enhance the amount of atmospheric $\mathrm{Hg}$ that is delivered within watersheds. Additionally, the organic and litter horizons in forest soils are major sites of $\mathrm{Hg}$ storage, particularly in association with soil organic matter (Obrist et al., 2011). Moreover, conifer-derived organic matter can lower the $\mathrm{pH}$ of a receiving waterbody (Allan et al., 1993).

Interestingly, we found negative relationships between fish $\mathrm{THg}$ concentrations and both sulfate and DOC while controlling for tree density within catchments. Because sulfate is a key component in the $\mathrm{MeHg}$ production process, dissolved $\mathrm{SO}_{4}$ concentrations often are positively correlated with $\mathrm{MeHg}$ concentrations in water, sediments, and biota (Mitchell and Gilmour, 2008). At high sulfate concentrations in reducing conditions, the rapid reduction to sulfide can subsequently inhibit $\mathrm{MeHg}$ production, resulting in a negative correlation (Benoit et al., 1999; Mehrotra and Sedlak, 2005; Windham-Myers et al., 2009). Interestingly, the sulfate concentrations in our study lakes ranged from 0.17 to $7.9 \mathrm{mg} / \mathrm{L}$, with a median concentration of only $0.36 \mathrm{mg} / \mathrm{L}$, making this an unlikely explanation. More likely, sulfate concentrations reflected an effect of $\mathrm{pH}$ on fish $\mathrm{Hg}$ concentrations because sulfate and acidification are often positively correlated in lakes (Skjelkvale et al., 2005; SommarugaWograth et al., 1997), and fish $\mathrm{Hg}$ concentrations are consistently negatively correlated with $\mathrm{pH}$ across lakes (Kamman et al., 2005; Snodgrass et al., 2000; Wiener et al., 2006). In this study, sulfate concentrations were positively correlated with $\mathrm{pH}\left(\mathrm{r}^{2}=0.25, \mathrm{p}=0.02\right)$, and sulfate may be a better indicator of longterm $\mathrm{pH}$ trends than instantaneous $\mathrm{pH}$ measures. Thus, interpretations of the sulfate effects should be made with caution.

Organisms, such as fish from high-elevation lakes, serve as important indicators for understanding how background concentrations and atmospheric deposition may be influencing remote environments. Additionally, they provide a unique opportunity to test for the influence of natural landscape characteristics on $\mathrm{Hg}$ cycling within lakes while reducing the complexity associated with anthropogenic impacts and other confounding factors. The $\mathrm{THg}$ concentrations in fishes from lakes in this study are generally lower than those from other remote, high-elevation lakes worldwide. In comparison with other high-elevation lakes from National Parks with similar fish assemblages in the western United States (Eagles-Smith et al., 2014), geometric mean THg concentrations in fishes from this study were 1.30 and 1.13 times higher than fish in Grand Teton and Crater Lake national parks (Eagles-Smith et al., 2014), but 2.35, 2.24, 2.1, 1.97, 1.91, 1.8, 1.67, 1.53, and 1.27 times lower than those in Yellowstone, Lassen Volcano, Glacier Bay, Olympic, Yosemite, Grand Canyon, Mount Rainier, Rocky Mountain, and North Cascades national parks, respectively (Eagles-Smith et al., 2014). Elsewhere, salmonid THg concentrations were 7 times higher in the French Pyrenees (Blais et al., 2006) than in this study, and various high altitude species across the Tibetan Plateau ranged between 0.251 and 1.218 $\mu \mathrm{g} / \mathrm{g}$ ww (Zhang et al., 2014). Although mean concentrations differed substantially across studies, a consistent theme among them all was the substantial variability in mean fish THg concentrations across sites, similarly highlighting the importance of landscape characteristics of fish $\mathrm{THg}$ concentrations. Developing a better understanding the relative importance of landscape drivers of $\mathrm{Hg}$ cycling in subalpine environments is important 
480 because these remote habitats are sensitive to shifts in climate and could be useful

481 indicators of how global climate change and associated shifts in ecosystem function may

482 influence $\mathrm{Hg}$ cycling, bioaccumulation, and risk in aquatic ecosystems.

483

\section{Acknowledgements}

485 This study was funded by the U.S. Department of Agriculture Forest Service, and the

486 U.S. Geological Survey Contaminant Biology Program. This study would not have been

487 possible without many dedicated field hours from a number of people. In particular, we

488 appreciate the support of David Salo, Alan Miller, Bob Rock, Leigh Woodruff, Mary

489 Ellen Emerick, Holly Akenson, Amy Busch, Randi Jandt, Tim Bailey, and Jeff Yanke.

490 We also are grateful for the efforts of Kevin Donner, John Pierce, Brandon Kowalski, and

491 Nick Baker for their laboratory efforts; and Patti Haggerty for her expertise and guidance

492 on geospatial analyses. We also thank David Salo, Alan Miller, Martin Fitzpatrick, Leigh

493 Woodruff, Gene Foster, and two anonymous reviewers for comments on previous

494 versions of the report. Any use of trade, product, or firm names is for descriptive

495 purposes only and does not imply endorsement by the U.S. Government. 


\section{Literature Cited}

Allan, C.J., Roulet, N.T., Hill, A.R., 1993. The biogeochemistry of pristine, headwater precambrian sheild watersheds - an analysis of material transport within a heterogeneous landscape. Biogeochemistry 22, 37-79.

Anderson, R.O., Neumann, R.M., 1996. Length, weight, and associated structural indices, in: Murphy, B.R., Willis, D.W. (Eds.), Fisheries Techniques. American Fisheries Society, Bethesdam Maryland, pp. 447-482.

Benoit, J.M., Gilmour, C.C., Mason, R.P., Heyes, A., 1999. Sulfide Controls on Mercury Speciation and Bioavailability to Methylating Bacteria in Sediment Pore Waters. Envionmental Science and Technology 33, 951-957.

Blais, J.M., Charpentie, S., Pick, F., Kimpe, L.E., St Amand, A., Regnault-Roger, C., 2006. Mercury, polybrominated diphenyl ether, organochlorine pesticide, and polychlorinated biphenyl concentrations in fish from lakes along an elevation transect in the French Pyrenees. Ecotoxicol Environ Saf 63, 91-99.

Bloom, N.S., 1992. On the chemical form of mercury in edible fish and marine invertebrate tissue. Canadian Journal of Fisheries and Aquatic Sciences 49, 10101017.

Burnham, K.P., Anderson, D.R., 2002. Model Selection and Multimodel Inference: A Practical Information-Theoretic Approach, 2nd ed. Springer-Verlag, New York.

Dittman, J.A., Driscoll, C.T., 2009. Factors influencing changes in mercury concentrations in lake water and yellow perch (Perca flavescens) in Adirondack lakes. Biogeochemistry 93, 179-196.

Drenner, R.W., Chumchal, M.M., Jones, C.M., Lehmann, C.M., Gay, D.A., Donato, D.I., 2013. Effects of mercury deposition and coniferous forests on the mercury contamination of fish in the South Central United States. Environ Sci Technol 47, 1274-1279.

Driscoll, C.T., Han, Y.-J., Chen, C.Y., Evers, D.C., Lambert, K.F., Holsen, T.M., Kamman, N.C., Munson, R.K., 2007. Mercury Contamination in Forest and Freshwater Ecosystems in the Northeastern United States. Bioscience 57, 17.

Dutton, J., Fisher, N.S., 2012. Influence of humic acid on the uptake of aqueous metals by the killifish Fundulus heteroclitus. Environ Toxicol Chem 31, 2225-2232.

Eagles-Smith, C., Willacker, J.J., Flanagan Pritz, C.M., 2014. Mercury in fishes from 21 national parks in the

Western United States-Inter and intra-park variation in concentrations and ecological risk. U.S. Geological Survey, p. 54.

Engstrom, D.R., Balogh, S.J., Swain, E.B., 2007. History of mercury inputs to Minnesota lakes: Influence of watershed disturbance and localized atmospheric deposition. Limnology and Oceanography 52, 2467-2483.

EPA, U.S., 2000. Test methods for evaluating solid waste, physical/chemical methods. Method 7473. , in: National Technical Information Service (Ed.), SW 846 U.S. EPA, Springfield, VA.

Evers, D., Wiener, J.G., Driscoll, C.T., Gay, D., Basu, N., Monson, B.A., Lambert, K.F., Morrison, H.A., Morgan, J.T., Williams, K., Soehl, A.G., 2011. Great Lakes Mercury Connections: The Extent and Effects of Mercury Pollution in the Great Lakes Region. Biodiversity Research Institute, Gorham, ME, p. 44. 
542

543

544

545

546

547

548

549

550

551

552

553

554

555

556

557

558

559

560

561

562

563

564

565

566

567

568

569

570

571

572

573

574

575

576

577

578

579

580

581

582

583

584

585

586
Friedli, H.R., Radke, L.F., Prescott, R., Hobbs, P.V., Sinha, P., 2003. Mercury emissions from the August 2001 wildfires in Washington State and an agricultural waste fire in Oregon and atmospheric mercury budget estimates. Global Biogeochemical Cycles 17, 1039.

Graydon, J.A., Louis, V.L.S., Hintelmann, H., Lindberg, S.E., Sandilands, K.A., Rudd, J.W.M., Kelly, C.A., Hall, B.D., Mowat, L.D., 2008. Long-Term Wet and Dry Deposition of Total and Methyl Mercury in the Remote Boreal Ecoregion of Canada. Environmental Science \& Technology 42, 8345-8351.

Greenfield, B.K., Hrabik, T.R., Harvey, C.J., Carpenter, S.R., 2001. Predicting mercury levels in yellow perch: use of water chemistry, trophic ecology, and spatial traits. Canadian Journal of Fisheries and Aquatic Sciences 58, 1419-1429.

Hall, B.D., Louis, V.L.S., Rolfhus, K.R., Bodaly, R.A., Beaty, K.G., Paterson, M.J., Cherewyk, K.A.P., 2005. Impacts of Reservoir Creation on the Biogeochemical Cycling of Methyl Mercury and Total Mercury in Boreal Upland Forests. Ecosystems 8, 248-266.

Johnson, B.M., Lepak, J.M., Wolff, B.A., 2015. Effects of prey assemblage on mercury bioaccumulation in a piscivorous sport fish. Science of the Total Environment 506, 330-337.

Kamman, N.C., Burgess, N.M., Driscoll, C.T., Simonin, H.A., Goodale, M.W., Linehan, J.C., Estabrook, R., Hutcheson, M.S., Major, A., Scheuhammer, A., Scruton, D.A., 2005. Mercury in Freshwater Fish of Northeast North America - A Geographic Perspective Based on Fish Tissue Monitoring Databases. Ecotoxicology 14, 163-180.

Lambertsson, L., Nilsson, M., 2006. Organic material: The primary control on mercury methylation and ambient methyl mercury concentrations in estuarine sediments. Environmental Science \& Technology 40, 1822-1829.

Lepak, J.M., Kinzli, K.D., Fetherman, E.R., Pate, W.M., Hansen, A.G., Gardunio, E.I., Cathcart, C.N., Stacy, W.L., Underwood, Z.E., Brandt, M.M., Myrick, C.A., Johnson, B.M., 2012. Manipulation of growth to reduce mercury concentrations in sport fish on a whole-system scale. Canadian Journal of Fisheries and Aquatic Sciences 69, 122-135.

Lindberg, S.E., Bullock, R., Ebinghaus, R., Engstrom, D.R., Feng, X., Fitzgerald, W.F., 2007. A synthesis of progress and uncertainties in attributing the sources of mercury in deposition. Ambio 36, 19-32.

Mason, R., Fitzgerald, W.F., Moreira, F., 1994. The biogeochemical cycling of elemental mercury: Anthropogenic influences. Geochimica Et Cosmochimica Acta 58, 3191-3198.

Mehrotra, A.S., Sedlak, D.L., 2005. Decrease in net mercury methylation rates following iron amendment to anoxic wetland sediment slurries. Envionmental Science and Technology 39.

Mitchell, C.P.J., Gilmour, C.C., 2008. Methylmercury production in a Chesapeake Bay salt marsh. Journal of Geophysical Research-Biogeosciences 113.

Obrist, D., Johnson, D.W., Lindberg, S.E., Luo, Y., Hararuk, O., Bracho, R., Battles, J.J., Dail, D.B., Edmonds, R.L., Monson, R.K., Ollinger, S.V., Pallardy, S.G., Pregitzer, K.S., Todd, D.E., 2011. Mercury distribution across 14 U.S. Forests. 
Part I: spatial patterns of concentrations in biomass, litter, and soils. Environ Sci Technol 45, 3974-3981.

Ohmann, J.L., Gregory, M.J., 2002. Predictive mapping of forest composition and structure with direct gradient analysis and nearest-neighbor imputation in coastal Oregon, U.S.A. Canadian Journal of Forest Research 32, 725-741.

Phillips, V.J., St Louis, V.L., Cooke, C.A., Vinebrooke, R.D., Hobbs, W.O., 2011. Increased mercury loadings to western Canadian alpine lakes over the past 150 years. Environ Sci Technol 45, $2042-2047$.

Pirrone, N., Cinnirella, S., Feng, X., Finkelman, R.B., Friedli, H.R., Leaner, J., Mason, R., Mukherjee, A.B., Stracher, G.B., Streets, D.G., Telmer, K., 2010. Global mercury emissions to the atmosphere from anthropogenic and natural sources. Atmospheric Chemistry and Physics Discussions 10, 4719-4752.

Ricker, W.E., 1979. Growth rates and models, in: Hoar, W.S., Randall, D.J., Brett, J.R. (Eds.), Fish Physiology. Academic Press, New York, pp. 677-743.

Rudd, J.W., 1995. Sources of methylmercury to freshwater ecosystems: A review. Water Air and Soil Pollution 80, 697-713.

Scheuhammer, A.M., Sandheinrich, M.B., 2008. Recent advances in the toxicology of methylmercury in wildlife. Ecotoxicology 17, 67-68.

Schmeltz, D., Evers, D.C., Driscoll, C.T., Artz, R., Cohen, M., Gay, D., Haeuber, R., Krabbenhoft, D.P., Mason, R., Morris, K., Wiener, J.G., 2011. MercNet: a national monitoring network to assess responses to changing mercury emissions in the United States. Ecotoxicology 20, 1713-1725.

Shanley, J.B., Kamman, N., Clair, T.A., Chalmers, A.T., 2005. Physical controls on total and methylmercury concentrations in streams and lakes of Northeastern USA. Ecotoxicology 14, 125-134.

Shanley, J.B., Mast, M.A., Campbell, D., Aiken, G.R., Krabbenhoft, D.P., Hunt, R.J., Walker, J.F., Schuster, P.F., Chalmers, A.T., Aulenbach, B.T., Peters, N.E., Marvin-Di Pasquale, M., Chow, D.W., Shafer, M.M., 2008. Comparison of total mercury and methylmercury cycling at five sites using the small watershed approach. Environmental Pollution 154.

Shanley, J.B., Moore, R., Smith, R.A., Miller, E.K., Simcox, A., Kamman, N., Nacci, D., Robinson, K., Johnston, J.M., Hughes, M.M., Johnston, C., Evers, D., Williams, K., Graham, J., King, S., 2012. MERGANSER: An Empirical Model To Predict Fish and Loon Mercury in New England Lakes. Environmental Science \& Technology 46, 4641-4648.

Sharma, C.M., Borgstrom, R., Huitfeldt, J.S., Rosseland, B.O., 2008. Selective exploitation of large pike Esox lucius - Effects on mercury concentrations in fish populations. Science of the Total Environment 399, 33-40.

Skjelkvale, B.L., Stoddard, J.L., Jeffries, D.S., Torseth, K., Hogasen, T., Bowman, J., Mannio, J., Monteith, D.T., Mosello, R., Rogora, M., Rzychon, D., Vesely, J., Wieting, J., Wilander, A., Worsztynowicz, A., 2005. Regional scale evidence for improvements in surface water chemistry 1990-2001. Environmental Pollution $137,165-176$.

Snodgrass, J., Jagoe, C.H., Bryan, A.L., Jr., Brant, H.A., Burger, J., 2000. Effects of trophic status and wetland morphology, hydroperiod, and water chemistry on 
mercury concentrations in fish. Canadian Journal of Fisheries and Aquatic Sciences 57, 171-180.

SommarugaWograth, S., Koinig, K.A., Schmidt, R., Sommaruga, R., Tessadri, R., Psenner, R., 1997. Temperature effects on the acidity of remote alpine lakes. Nature 387, 64-67.

St. Louis, V.L., Rudd, J.W., Kelly, C.A., Beaty, K.G., Bloom, N.S., Flett, R.J., 1994. Importance of wetlands as sources of methyl mercury to boreal forest ecosystems. Canadian Journal of Fisheries and Aquatic Sciences 51, 1065-1076.

Stafford, C.P., Hansen, B., Stanford, J.A., 2004. Mercury in Fishes and Their Diet Items from Flathead Lake, Montana. Transactions of the American Fisheries Society 133, 349-357.

Tebatchnick, M.D., Nogaro, G., Hammerschmidt, C.R., 2012. Potential sources of methylmercury in tree foliage. Environmental Pollution 160, 82-87.

Trudel, M., Rasmussen, J.B., 2006. Bioenergetics and mercury dynamics in fish: a modelling perspective. Canadian Journal of Fisheries and Aquatic Sciences 63, 1890-1902.

Wiener, J.G., Bodaly, R.A., Brown, S.S., Lucotte, M., Newman, M.C., Porcella, D.B., Reash, R.J., Swain, E.B., 2007. Monitoring and evaluating trends in methylmercury accumulation in aquatic biota, in: Harris, R.C., Krabbenhoft, D.P., Mason, R., Murray, M.W., Reash, R.J., Saltman, T. (Eds.), Ecosystem Responses to Mercury Contamination: Indicators of Change. CRC Press/Taylor and Francis, Boca Raton, Florida, pp. 87-122.

Wiener, J.G., Knights, B.C., Sandheinrich, M.B., Jeremiason, J.D., Brigham, M.E., Engstrom, D.R., Woodruff, L.G., Cannon, W.F., Balogh, S.J., 2006. Mercury in soils, lakes, and fish in Voyageurs National Park (Minnesota): Importance of atmospheric deposition and ecosystem factors. Environmental Science \& Technology 40, 6261-6268.

Williams, B.K., Nichols, J.D., Conroy, M.J., 2002. Analysis and Management of Animal Populations: Modeling, Estimation. amd Decision Making. Academic Press, San Diego, CA.

Windham-Myers, L., Marvin-Dipasquale, M., Krabbenhoft, D.P., Agee, J.L., Cox, M.H., Heredia-Middleton, P., Coates, C., Kakouros, E., 2009. Experimental removal of wetland emergent vegetation leads to decreased methylmercury production in surface sediment. Journal of Geophysical Research-Biogeosciences 114.

Wren, C.D., Scheider, W.A., Wales, D.L., Muncaster, B.W., Gray, L.M., 1991. Relation between mercury concentration in walleye (Stizostedion vitreum vitreum) and northern pike (Esox Lucius), in Ontario lakes and influence of environmental factors. Canadian Journal of Fisheries and Aquatic Sciences 48.

Zhang, Q., Pan, K., Kang, S., Zhu, A., Wang, W.X., 2014. Mercury in wild fish from high-altitude aquatic ecosystems in the Tibetan Plateau. Environ Sci Technol 48, 5220-5228. 


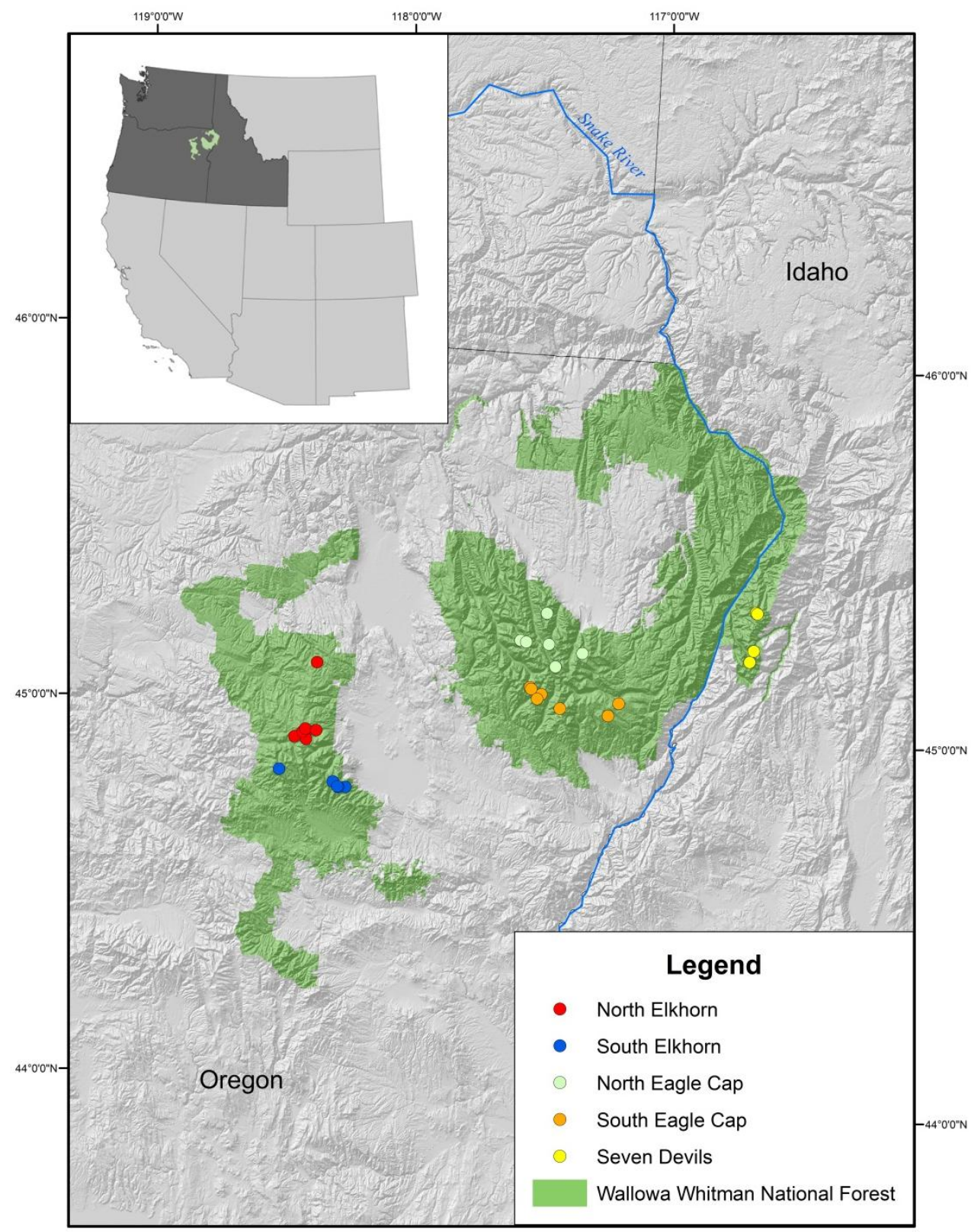

Figure 1. Map of the Wallowa-Whitman National Forest in northeastern Oregon and western Idaho. Colored symbols represent lakes sampled in various regions of the Forest. 

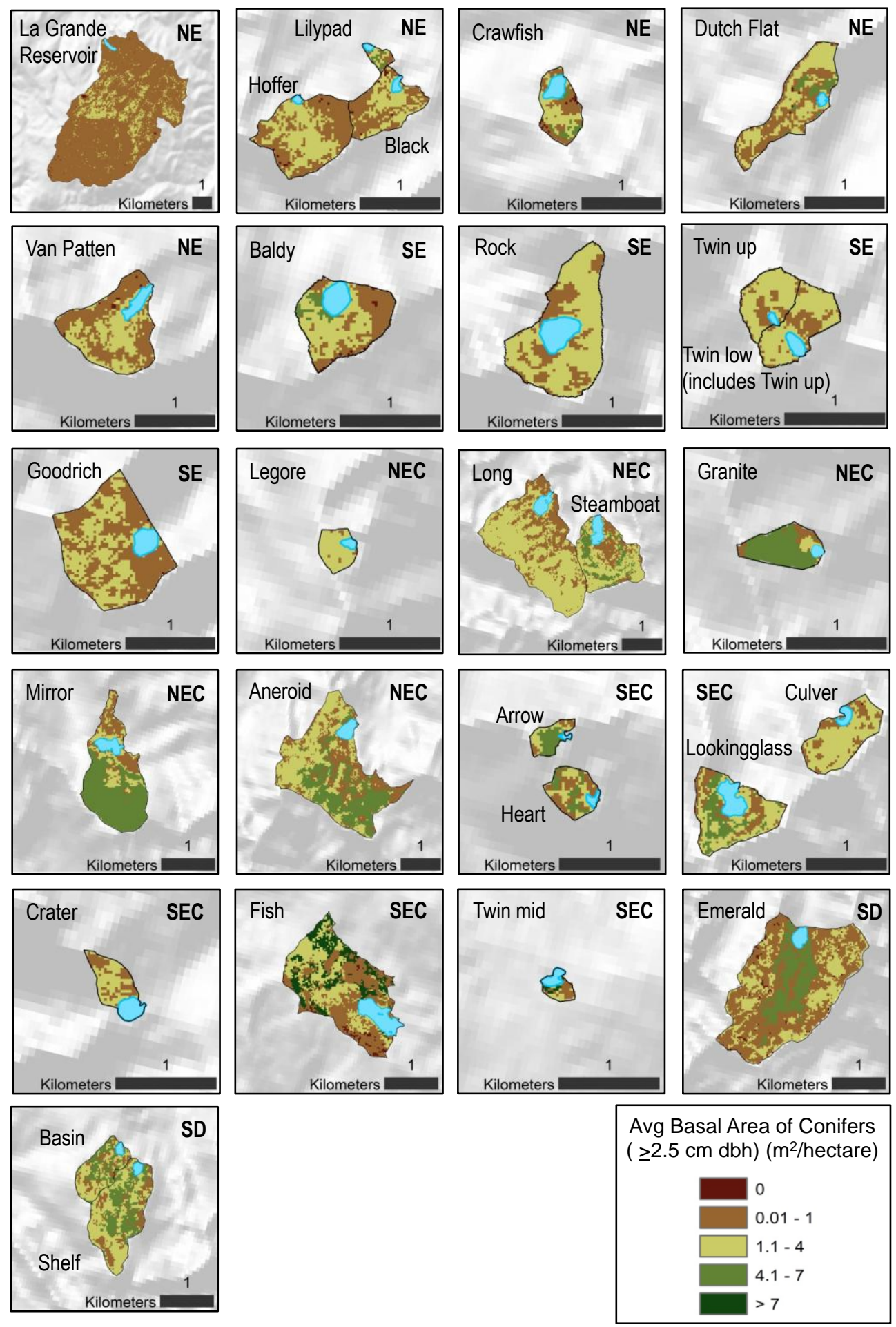

Figure 2. Conifer density measured as basal area $\left(\mathrm{m}^{2} /\right.$ hectare) of all conifers $>2.5$ $\mathrm{cm}$ dbh for Wallowa Whitman National Forest lake catchments. Regions in bold: NE=North Elkhorn; SE=South Elkhorn; NEC=North Eagle Cap; SEC=South Eagle Cap; $\mathrm{SD}=$ Seven Devils. Light blue areas represent lake boundaries. Note, incomplete data for Ruth Lake catchment. 


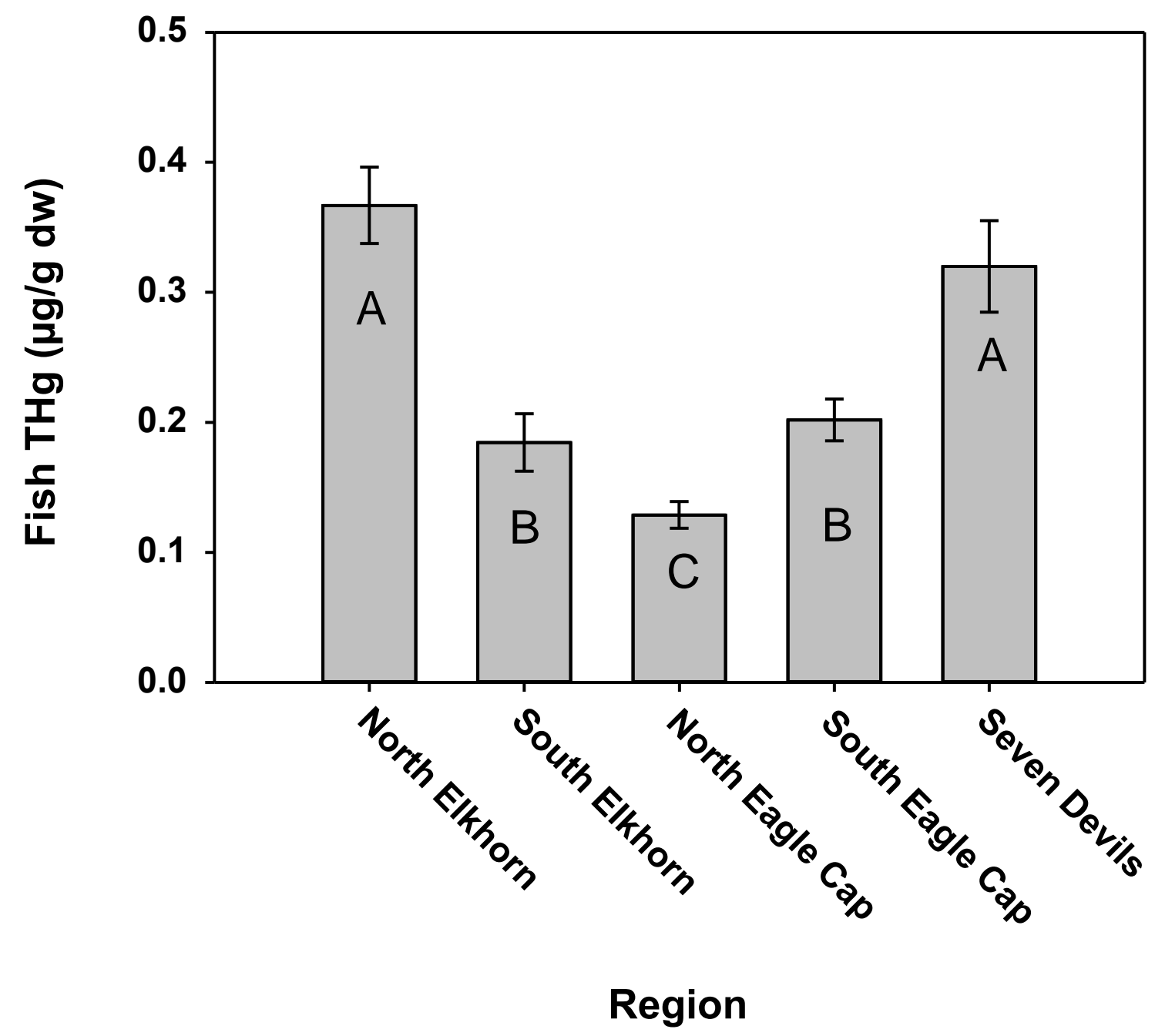

Figure 3. Fish muscle total mercury (THg) concentrations (back-transformed leastsquare means \pm standard error) for the 5 study regions in the Wallowa-Whitman National Forest. Differing letters among bars indicate statistically significant differences in THg concentrations at alpha $=0.05$ 


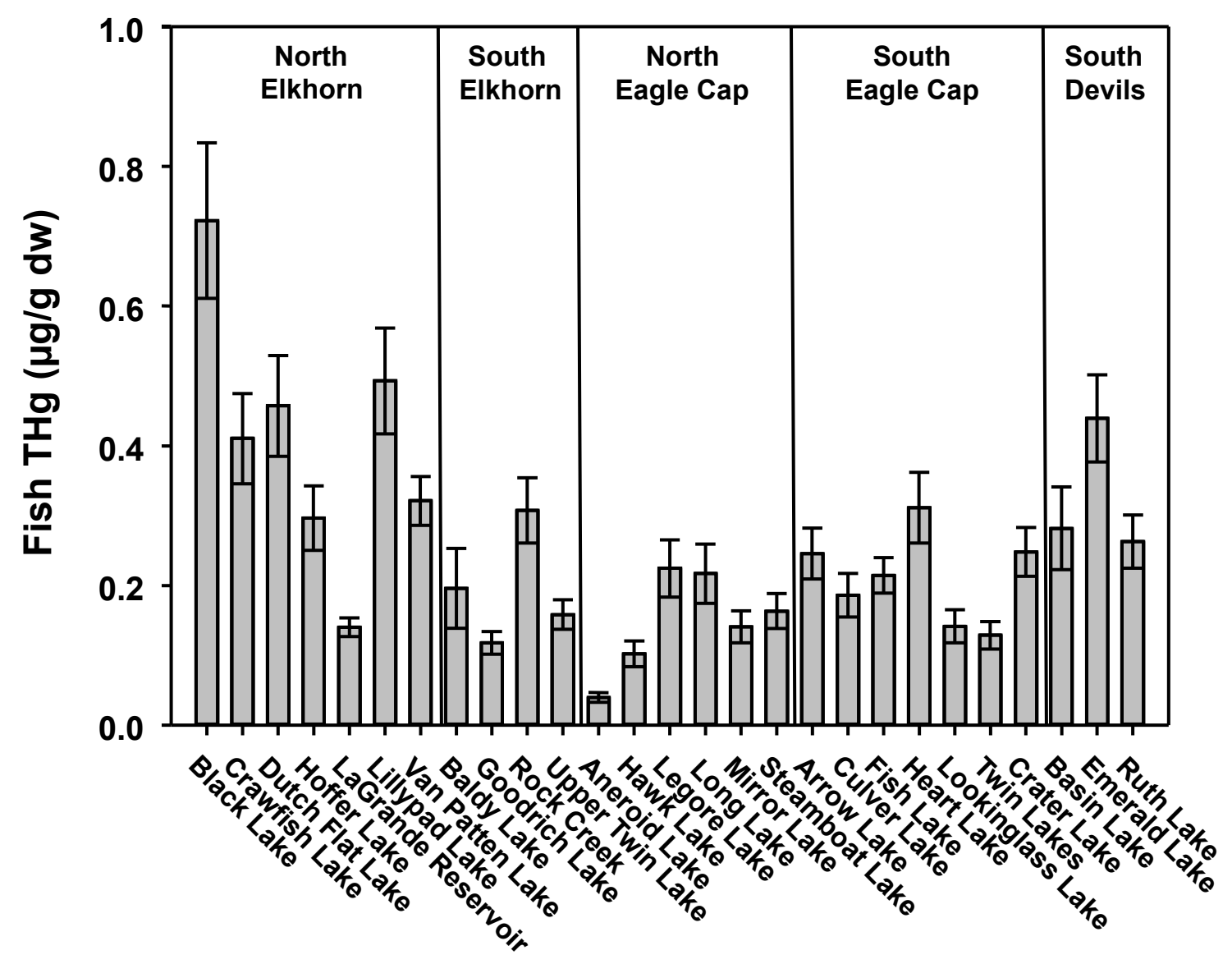

\section{Lake Name}

Figure 4. Fish muscle total mercury (THg) concentrations (back transformed leastsquare means \pm standard error) for the study lakes in the Wallowa-Whitman National Forest, northeastern Oregon and western Idaho. 


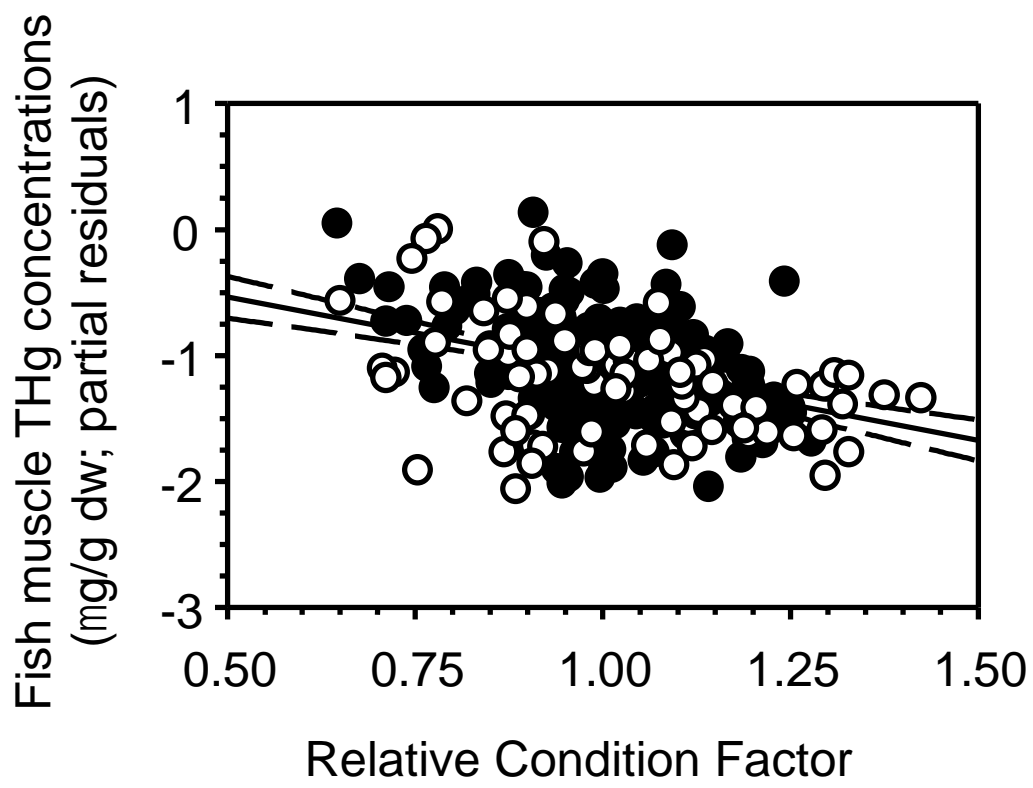

Figure 5. Fish total mercury (THg) concentrations (partial residual plot) in relation to relative condition factor. Solid circles indicate brook trout, open circles represent rainbow trout. Partial residuals are derived from the global mixed-effects general linear model that includes species, lake, region, and fish length. Cutthroat trout data were excluded from this figure because they only occurred in a single lake and could not be included in the model with the other species. 


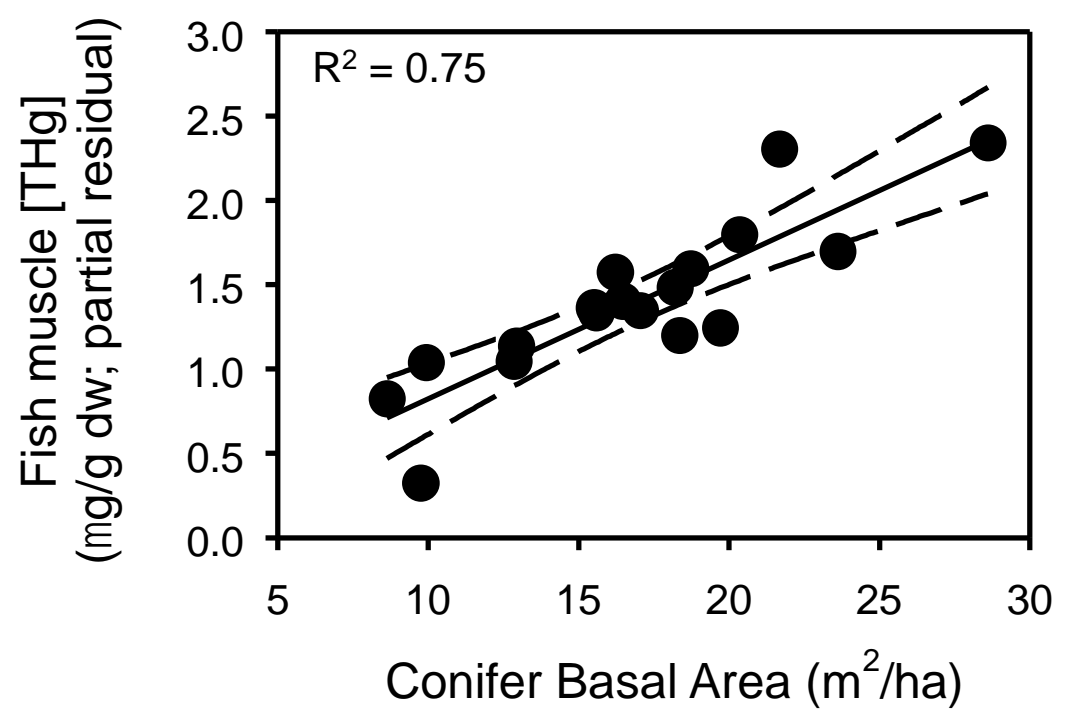

Figure 6. Relationship between conifer density within a lake's catchment (quantified as conifer basal area $>2.5 \mathrm{~cm}$ diameter at breast height) and fish THg concentrations. Data are plotted as partial residuals from the best model to adjust for the effects of other independent factors on fish THg concentrations. Each data point represents a single lake least-square mean value. 


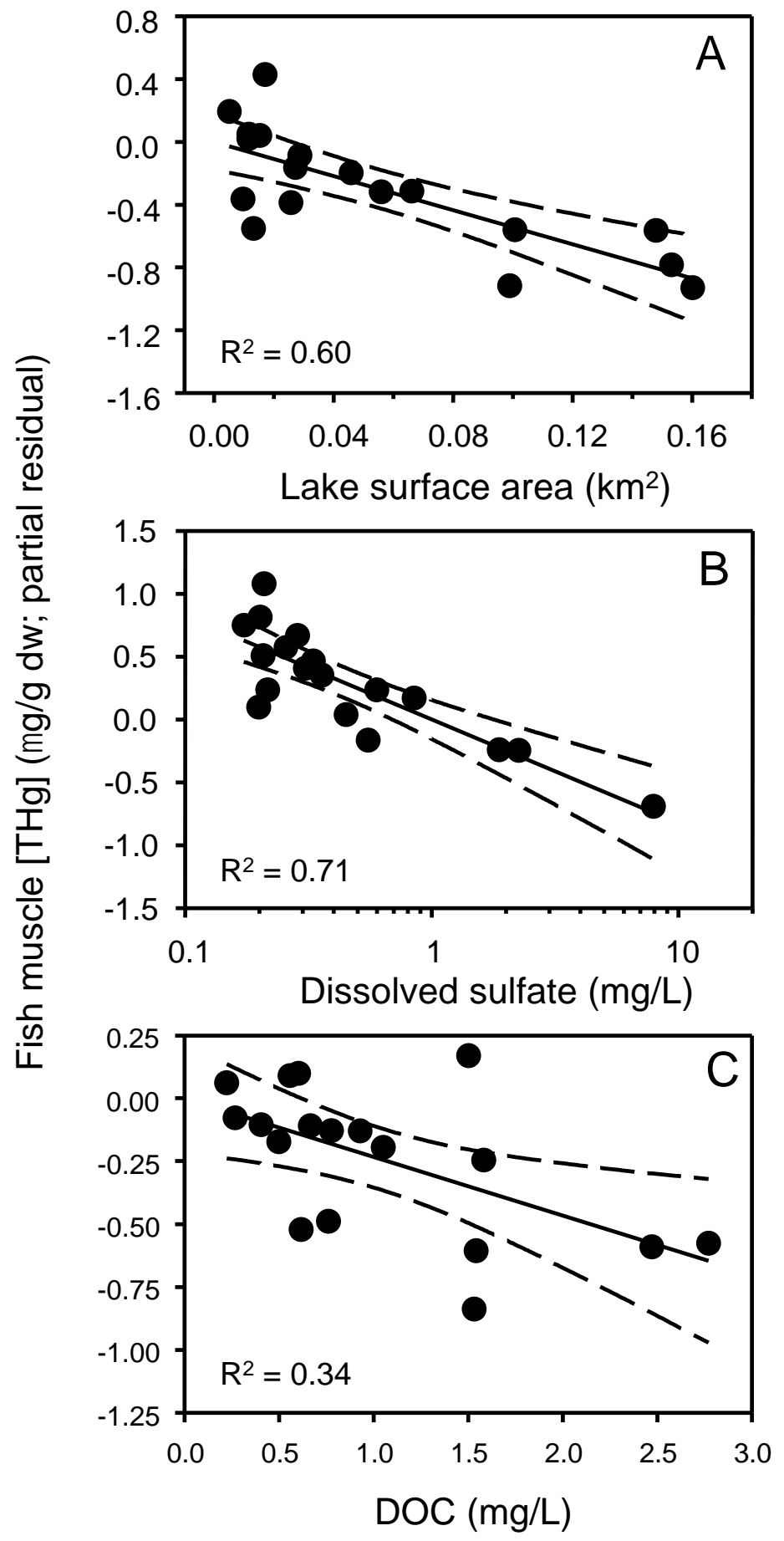

Figure 7. Influence of (A) lake surface area, (B) dissolved sulfate, and (C), dissolved organic carbon on fish THg concentrations in the Wallowa-Whitman National Forest, northeaster Oregon and western Idaho. Data are plotted as partial residuals from the best model to adjust for the effect of other independent factors on fish $\mathrm{THg}$ concentrations. 
Table 1. Fish catch data and size ranges from subalpine lakes in the Wallowa-Whitman National Forest, northeastern Oregon and western Idaho.

\begin{tabular}{|c|c|c|c|c|c|c|c|c|c|c|c|c|}
\hline \multirow[b]{2}{*}{ Lake Name } & \multicolumn{3}{|c|}{ Brook trout } & \multicolumn{3}{|c|}{ Rainbow trout } & \multicolumn{3}{|c|}{ Cutthroat trout } & \multicolumn{3}{|c|}{ Lake trout } \\
\hline & $\begin{array}{c}\text { SL Range } \\
\text { (mm) }\end{array}$ & $\begin{array}{l}\text { Mean SL } \\
(\mathrm{mm})\end{array}$ & $\mathrm{N}$ & $\begin{array}{c}\text { SL Range } \\
(\mathrm{mm})\end{array}$ & $\begin{array}{c}\text { Mean SL } \\
(\mathrm{mm})\end{array}$ & $\mathbf{N}$ & $\begin{array}{c}\text { SL Range } \\
(\mathrm{mm})\end{array}$ & $\begin{array}{c}\text { Mean SL } \\
(\mathrm{mm})\end{array}$ & $\mathbf{N}$ & $\begin{array}{l}\text { SL Range } \\
(\mathrm{mm})\end{array}$ & $\begin{array}{c}\text { Mean SL } \\
(\mathrm{mm})\end{array}$ & $\mathbf{N}$ \\
\hline Aneroid Lake & $145-265$ & 212.5 & 10 & NA & 290 & 1 & -- & -- & -- & -- & -- & -- \\
\hline Arrow Lake & -- & -- & -- & $165-320$ & 238.4 & 10 & -- & -- & -- & -- & -- & -- \\
\hline Baldy Lake & $204-257$ & 230.5 & 2 & -- & -- & -- & -- & -- & -- & -- & -- & -- \\
\hline Basin Lake & -- & -- & -- & $218-320$ & 286.3 & 6 & -- & -- & -- & -- & -- & -- \\
\hline Black Lake & $161-248$ & 210.9 & 10 & -- & -- & -- & -- & -- & -- & -- & -- & -- \\
\hline Crater Lake & $245-276$ & 263.6 & 5 & $250-290$ & 268.2 & 9 & -- & -- & -- & -- & -- & -- \\
\hline Crawfish Lake & $152-220$ & 188.3 & 10 & -- & -- & -- & -- & -- & -- & -- & -- & -- \\
\hline Culver Lake & $129-175$ & 154.9 & 11 & -- & -- & -- & -- & -- & -- & -- & -- & -- \\
\hline Dutch Flat Lake & $170-245$ & 210.2 & 10 & -- & -- & -- & -- & -- & -- & -- & -- & -- \\
\hline Emerald Lake & $150-196$ & 167.9 & 15 & -- & -- & -- & -- & -- & -- & -- & -- & -- \\
\hline Fish Lake & $182-215$ & 201.1 & 8 & $200-300$ & 244.4 & 9 & -- & -- & -- & -- & -- & -- \\
\hline Goodrich Lake & $147-206$ & 184.4 & 15 & -- & -- & -- & -- & -- & -- & -- & -- & -- \\
\hline Granite/Hawk Lake & -- & -- & -- & $215-238$ & 225.5 & 6 & -- & -- & -- & -- & -- & -- \\
\hline Heart Lake & $162-220$ & 198.8 & 8 & -- & -- & -- & -- & -- & -- & -- & -- & -- \\
\hline Hoffer Lake & $133-190$ & 167.9 & 10 & -- & -- & -- & -- & -- & -- & -- & -- & -- \\
\hline LaGrande Reservoir & $150-239$ & 199.7 & 15 & $154-250$ & 202.4 & 12 & -- & -- & -- & -- & -- & -- \\
\hline Legore Lake & -- & -- & -- & $146-247$ & 204.7 & 9 & -- & -- & -- & -- & -- & -- \\
\hline Lilypad Lake & $160-220$ & 177.1 & 10 & -- & -- & -- & -- & -- & -- & -- & -- & -- \\
\hline Long Lake & $205-220$ & 215.8 & 5 & -- & -- & -- & -- & -- & -- & -- & -- & -- \\
\hline Lookinglass Lake & $105-178$ & 150.1 & 10 & -- & -- & -- & -- & -- & -- & 659 & -- & 1 \\
\hline Mirror Lake & $98-174$ & 138.1 & 12 & -- & -- & -- & -- & -- & -- & -- & -- & -- \\
\hline Rock Creek & $115-204$ & 168.1 & 15 & -- & -- & -- & -- & -- & -- & -- & -- & -- \\
\hline Ruth Lake & $174-218$ & 196.6 & 8 & $290-330$ & 303.3 & 3 & -- & -- & -- & -- & -- & -- \\
\hline Shelf Lake & -- & -- & -- & -- & -- & -- & $133-265$ & 191.2 & 11 & -- & -- & -- \\
\hline Steamboat Lake & $125-209$ & 183.9 & 11 & -- & -- & -- & -- & -- & -- & -- & -- & -- \\
\hline Twin Lakes_Eagle Cap & -- & -- & -- & $210-285$ & 233.2 & 10 & -- & -- & -- & -- & -- & -- \\
\hline Upper Twin Lakes_Elkhorns & $153-231$ & 175.2 & 20 & -- & -- & -- & -- & -- & -- & -- & -- & -- \\
\hline Van Patten Lake & $145-215$ & 177.8 & 10 & $161-200$ & 183.1 & 10 & -- & -- & -- & -- & -- & -- \\
\hline
\end{tabular}


Table 2. Ranking of candidate models describing physical and chemical variables influencing fish THg concentrations in the Wallowa-Whitman National Forest, northeastern Oregon and western Idaho.

[Models presented include only those that were within 8 AICC units of the top model $(\triangle \mathrm{AICC}=0)$ and the null (intercept) models; ${ }^{\mathrm{a}}$ Variables considered included basal area, lake area, lake elevation, lake catchment area, ratio of lake area to lake catchment area, lake pH, acid neutralizing capacity (ANC), lake sulfate $\left(\mathrm{SO}_{4}\right)$, and dissolved organic carbon (DOC); ${ }^{\mathrm{b}}$ Number of estimated parameters in the model including the intercept and variance; ${ }^{\mathrm{C}} \mathrm{Second}$-order Akaike's Information Criterium (AICc); ${ }^{\mathrm{d}}$ The difference in the value between the AICc of the current model and the value of the most parsimonious model; ${ }^{\mathrm{e}}$ Likelihood of the model given the data, relative to candidate models; ${ }^{\mathrm{f}}$ The weight of the evidence that the top model is better than the selected model, given the candidate model set ].

\begin{tabular}{|c|c|c|c|c|c|c|c|c|}
\hline Model Structure & $\mathrm{n}$ & $\mathrm{K}^{\mathrm{b}}$ & $-2 \log L$ & $\mathrm{AlC}_{c^{c}}$ & $\Delta \mathrm{AIC}_{c^{d}}$ & $\mathbf{w}_{i}^{e}$ & $\begin{array}{c}\text { Evidence } \\
\text { ratio }^{f}\end{array}$ & $r^{2}$ \\
\hline Basal area + lake area $+\mathrm{SO}_{4}+\mathrm{DOC}$ & 18 & 6 & -1.673 & 17.963 & 0.000 & 0.56 & 1.00 & 0.87 \\
\hline $\mathrm{Basal}$ area + lake area $+\mathrm{SO}_{4}$ & 18 & 5 & 4.986 & 19.986 & 2.023 & 0.20 & 1.58 & 0.71 \\
\hline Basal area + lake area $+\mathrm{SO}_{4}+\mathrm{ANC}$ & 18 & 6 & 3.096 & 22.733 & 4.770 & 0.05 & 2.10 & 0.75 \\
\hline Basal area + lake area $+\mathrm{SO}_{4}+$ catchment area & 18 & 6 & 4.716 & 24.353 & 6.390 & 0.02 & 2.60 & 0.76 \\
\hline Basal area + lake area $+\mathrm{SO}_{4}+$ elevation & 18 & 6 & 4.887 & 24.524 & 6.561 & 0.02 & 2.61 & 0.72 \\
\hline Basal area + lake area $+\mathrm{SO}_{4}+$ lake area to catchment ratio & 18 & 6 & 4.960 & 24.596 & 6.634 & 0.02 & 2.89 & 0.72 \\
\hline Basal area + lake area $+\mathrm{SO}_{4}+\mathrm{pH}$ & 18 & 6 & 4.979 & 24.615 & 6.653 & 0.02 & 2.95 & 0.71 \\
\hline Basal area + lake area $+\mathrm{ANC}+\mathrm{pH}$ & 18 & 6 & 5.039 & 24.676 & 6.713 & 0.02 & 2.98 & 0.81 \\
\hline Basal area $+\mathrm{SO}_{4}+$ catchment area & 18 & 5 & 10.012 & 25.013 & 7.050 & 0.02 & 3.07 & 0.53 \\
\hline Basal area $+\mathrm{SO}_{4}$ & 18 & 4 & 14.518 & 25.596 & 7.633 & 0.01 & 3.40 & 0.50 \\
\hline Intercept & 18 & 2 & 34.997 & 39.798 & 21.835 & 0.00 & 55130.92 & - \\
\hline
\end{tabular}


Table 3. Ranking of candidate models describing physical variables influencing fish THg concentrations in the Wallowa-Whitman National Foresta, northeastern Oregon and western Idaho.

\begin{tabular}{|c|c|c|c|c|c|c|c|c|}
\hline Model Structure & n & $\mathrm{K}^{b}$ & $-2 \operatorname{LogL}$ & $\mathrm{AlC}_{c^{c}}$ & $\Delta \mathrm{AlC}_{c^{d}}$ & $\mathbf{w i}^{\mathrm{e}}$ & $\begin{array}{c}\text { Evidence } \\
\text { ratio } f\end{array}$ & $\mathbf{r}^{2}$ \\
\hline Basal area + lake area & 26 & 4 & 30.375 & 40.279 & 0.000 & 0.51 & 1.00 & 0.46 \\
\hline Basal area + lake area + lake area to catchment ratio & 26 & 5 & 30.226 & 43.226 & 2.947 & 0.12 & 4.36 & 0.46 \\
\hline Basal area + lake area + catchment area & 26 & 5 & 30.309 & 43.309 & 3.029 & 0.11 & 4.55 & 0.46 \\
\hline Basal area + lake area + elevation & 26 & 5 & 30.365 & 43.365 & 3.085 & 0.11 & 4.68 & 0.46 \\
\hline Basal area + lake area + catchment area + lake area to catchment ratio & 26 & 6 & 30.016 & 46.437 & 6.158 & 0.02 & 21.73 & 0.47 \\
\hline Basal area + lake area + catchment area + elevation & 26 & 6 & 30.047 & 46.468 & 6.189 & 0.02 & 22.07 & 0.47 \\
\hline Basal area & 26 & 3 & 39.503 & 46.594 & 6.315 & 0.02 & 23.51 & 0.23 \\
\hline Basal area + lake area + lake area to catchment ratio + elevation & 26 & 6 & 30.218 & 46.639 & 6.360 & 0.02 & 24.05 & 0.46 \\
\hline Intercept & 26 & 2 & 46.336 & 50.858 & 10.579 & 0.00 & 198.20 & - \\
\hline
\end{tabular}

[Model presented include only those that were within 8 AICC units of the top model $(\triangle \mathrm{AICC}=0)$ and the null (intercept) models;

${ }^{\mathrm{a}}$ Variables considered included basal area, lake area, lake elevation, lake catchment area, and ratio of lake area to lake catchment area; ${ }^{b} \mathrm{Number}$ of estimated parameters in the model including the intercept and variance; ${ }^{\mathrm{c}}$ Second-order Akaike's Information Criterium (AICc); ${ }^{\mathrm{d}}$ The difference in the value between the AICc of the current model and the value of the most parsimonious model; ${ }^{\mathrm{e}}$ Likelihood of the model given the data, relative to candidate models; ${ }^{\mathrm{f}} \mathrm{The}$ weight of the evidence that the top model is better than the selected model, given the candidate model set]. 